\title{
Energy efficiency improvement in an ethylene plant propylene refrigeration cycle $(\mathrm{C} 3 \mathrm{R})$
}

\author{
Delano Mendes de Santana ${ }^{1,2}$ - Anderson Luis Cassinoni de Oliveira ${ }^{3}$. \\ Evelyn Kraneck $^{3}$ - Thais Helena A. Bierrenbach de Camargo ${ }^{3}$. \\ Reinaldo Antonio Cardoso ${ }^{3}$
}

Received: 30 March 2017/ Accepted: 16 July 2017 / Published online: 25 July 2017

(c) The Author(s) 2017. This article is an open access publication

\begin{abstract}
A typical refrigeration cycle in an ethylene plant utilizes propene as fluid. When C3R is still in the warm zone, there is some process heat exchangers that leave it sub-cooled. This creates the opportunity for operational improvement in these systems which will result in less parasite steam formation on cycle expansion zone. The objective is analyze this energy efficiency improvement opportunity, showing the financial and energy earnings. The methodology applied to achieve this improvement in the energy efficiency of this cycle is based on: mass and energy balance calculation, design data comparison, and analysis of differences between the actual values and the design reference. An action plan was developed with necessary implementation steps and earnings calculations. The annual amount realized was around one million dollars in 2015. In terms of natural resources, this work is bringing an average reduction of $1.07 \mathrm{~kg} / \mathrm{s}$ of steam, representing an amount of approximately $2.12 \mathrm{MW}$. This gain is about $2 \%$ of the turbine consumption. This framework can be applied at any Ethylene plant that has the similar equipments.
\end{abstract}

Keywords Energy efficiency - Operation improvement · Propylene refrigeration cycle $(\mathrm{C} 3 \mathrm{R}) \cdot$ Ethylene plant

Delano Mendes de Santana

delano.santana@braskem.com;

delano.mendes@ufabc.edu.br

1 Process Engineering, BRASKEM, Av. Presidente Costa e Silva, 1178, Santo André, SP 09270-901, Brazil

2 CECS, Centro de Engenharia, Modelagem e Ciências Sociais Aplicadas, UFABC, Universidade Federal do ABC, Santo André, Brazil

3 BRASKEM, Santo André, Brazil

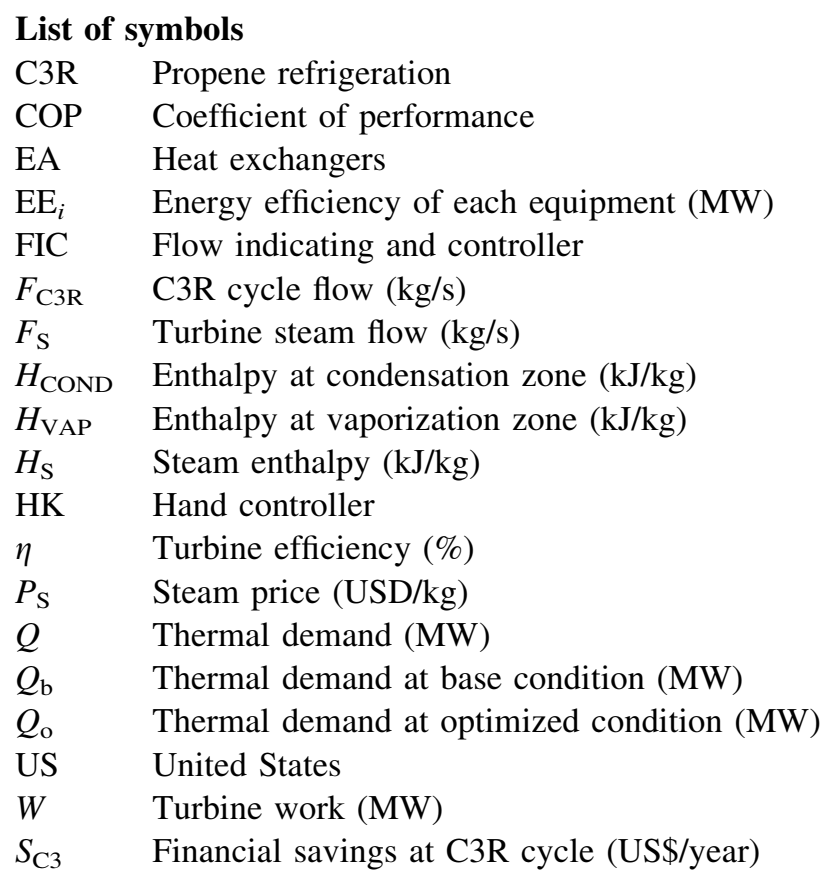

\section{Introduction}

Energy efficiency has been sought by companies worldwide as a perpetuation strategy. Numerous academic papers have been developed, for example, in Italy [1], Canada [2], Sweden [3], Nigeria [4], United States [5], Germany and Colombia [6], France [7], Japan [8], China [9] and Thailand [10], reinforcing the importance of the subject in the global energy context.

Worldwide, trend of energy consumption in chemicals sector is growing by $50 \%$ until 2030 , according to the study 
of Utrecht University in Netherlands [11]. According to [12], energy costs in Brazilian industry grew by $3.8 \%$ between the first and second quarter of 2014 and continues in upward trend.

According to [13] energy in Brazil is a typical bottleneck. Energetic cost of a typical petrochemical plant in Brazil as Braskem, for example, represent $13.4 \%$ of total product costs [14].

The US Department of Energy [15] affirms that $8 \%$ of the steam is consumed at turbines on the chemical sector. In ethylene's plants they consume up to $15 \%$ of the steam generation, as in the propene refrigerant cycle turbine.

The refrigerant cycle fluid is propene (three carbons). For this reason, the cycle is called $\mathrm{C} 3 \mathrm{R}$ - propene refrigerant. Figure 1 shows a simplified schematic of this C3R refrigeration cycle. The compressor has four stages and each stage has a suction drum. The discharge is condensed by water and distributed to the cycle by the accumulator vessel.

The temperatures at the accumulator vessel are normally around $25-40{ }^{\circ} \mathrm{C}$ on average. This fluid can be considered as hot fluid at some point in process, especially in the ethylene plant cold area. On the studied plant, these process currents are used in heat exchangers, as heat integration, as listed below.

- EA-001: The last cold box exchanger, which combine the hot stream C3R with methane, hydrogen, recycle ethylene and recycle ethane at cryogenic conditions;

- EA-002: $A / B$ The ethylene product vaporizer;

- EA-003: The deethanizer feed heater.

Figure 2 illustrates the described heat exchangers, highlighted in red. They are located downstream the accumulator vessel. The EA-001 and EA-002 send the liquid to the second stage suction drum and the EA-003 send the liquid to the fourth stage suction drum.

This thermal exchange let the liquid at sub-cooled state and generates less parasite propene vapor in the compressor suction drums. Figure 3 illustrates this energy utilization schematic drawing. The red zone is where heat integration exchangers use C3R still warm, leaving it subcooled. In the green zone will be less parasite vapor formation with the same thermal exchange. This phenomena increase the coefficient of performance (COP) and increase the energy efficiency.

The parasite vapor is generated without energy transfer, so it should be avoided. When the pressure decrease in the valves at the cycle, vapor are generated thermodynamically, because the condensation enthalpy is higher after the valves. Figure 4 illustrate the parasite vapor generation. It is generated downstream the valves and this parasite vapor flow to the suction drum consuming power at the turbine and decreasing the COP.

The COP is calculated by the Eq. 1 . Where $Q$ is the thermal demand of the cycle and $\mathrm{W}$ is the turbine work. $\mathrm{COP}$ is a type of efficiency measure. If the work increase with the same thermal demand, the COP will decrease, indicating a poor energy efficiency:

$\mathrm{COP}=Q_{/ W}$.

The thermal demand can be calculated by the difference between the enthalpy at the vaporization zone $\left(H_{\mathrm{vap}}\right)$ and the enthalpy at the condensation zone $\left(H_{\text {cond }}\right)$ multiplied by the $\mathrm{C} 3 \mathrm{R}$ cycle flow $\left(F_{\mathrm{C} 3 \mathrm{R}}\right)$, as showed on the Eq. 2 and the Fig. 5:

$Q=\left(H_{\text {vap }}-H_{\text {cond }}\right) \times F_{\mathrm{C} 3 \mathrm{R}}$.

$H_{\text {cond }}$ is directly proportional to temperature of subcooling on the condensation zone. By the Eq. 1, considering fixed the thermal demand $(Q)$ and the vaporization condition $\left(H_{\mathrm{vap}}\right)$, when the $H_{\text {cond }}$ is lower, the $\mathrm{C} 3 \mathrm{R}$ flow $\left(F_{\mathrm{C} 3 \mathrm{R}}\right)$ is lower proportionally.

The cycle turbine work $(W)$ is directly proportional to cycle flow $\left(F_{\mathrm{C} 3 \mathrm{R}}\right)$. So if the $F_{\mathrm{C} 3 \mathrm{R}}$ is lower, the work is lower, reducing the steam turbine consumption, saving energy.
Fig. 1 Propene refrigeration cycle (C3R) schematic

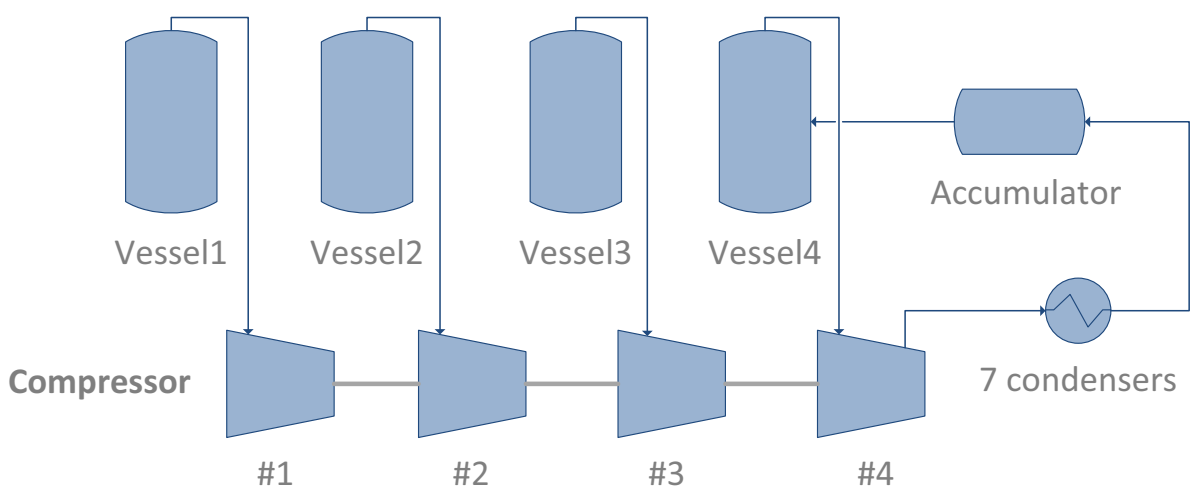


Fig. 2 Energy utilization schematic

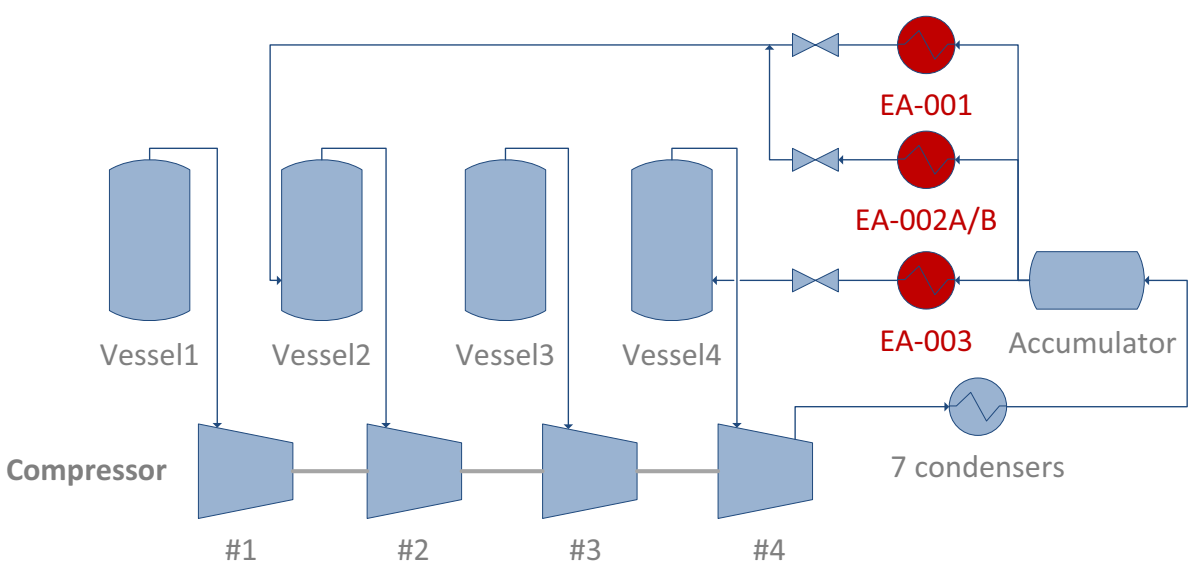

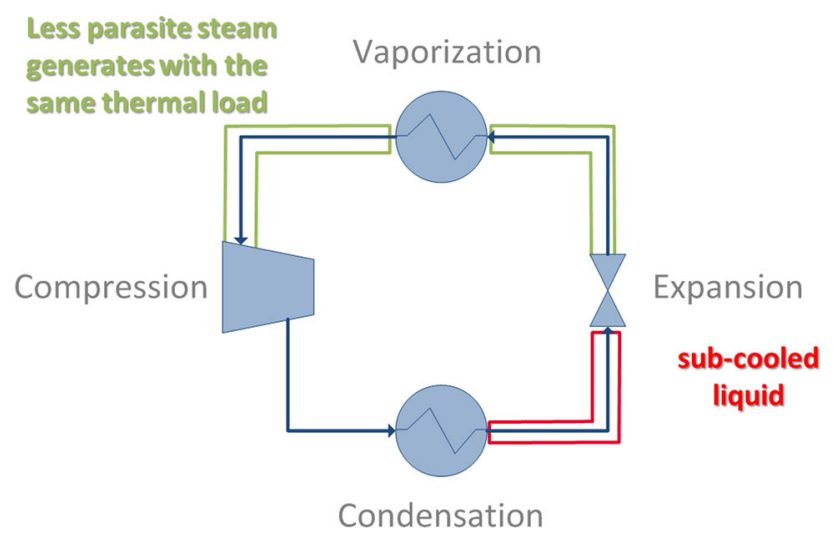

Fig. 3 Energy utilization schematic

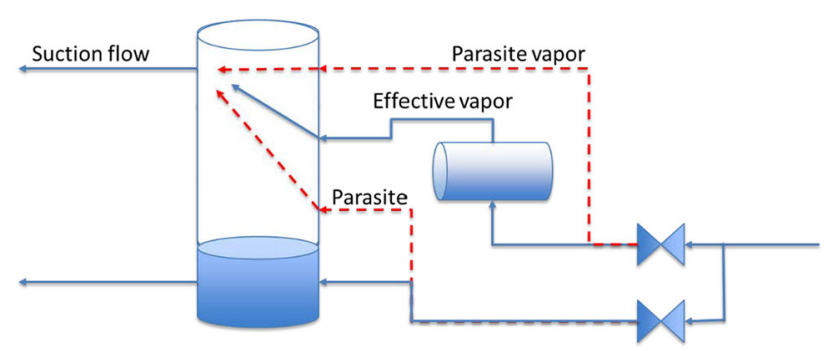

Fig. 4 Parasite vapor

The aim of this paper is analyze this energy efficiency improvement opportunity, showing the financial and energy earnings.

\section{Materials and methods}

The C3R cycle energy efficiency of each equipment $\left(\mathrm{EE}_{i}\right)$ should be measured by the thermal demand difference, that is calculated by the difference between the thermal demand at the optimized condition $\left(Q_{\mathrm{o}}\right)$ and the thermal demand on the base condition $\left(Q_{\mathrm{b}}\right)$ as showed on the Eq. 3. The

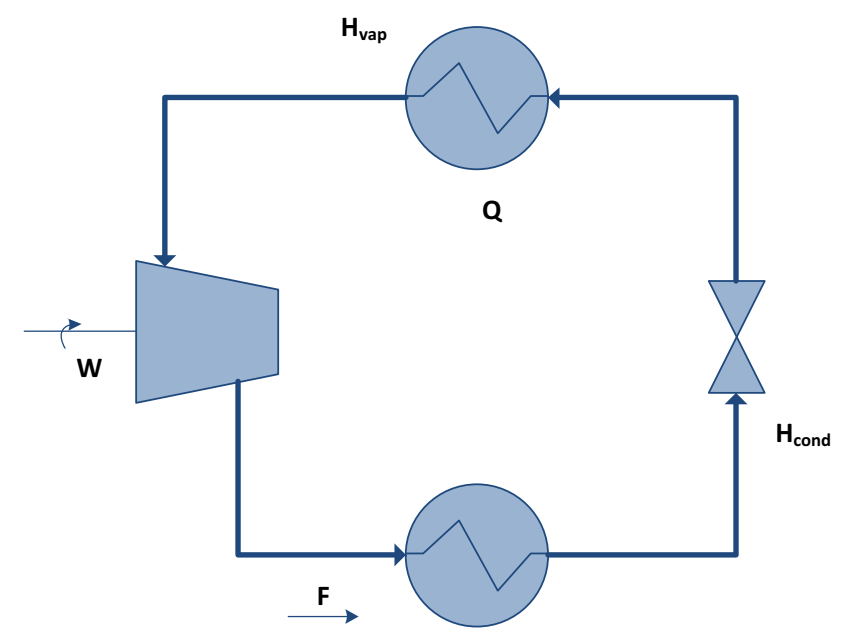

Fig. 5 Coefficient of performance and thermal demand

optimized condition is the scenario after the modifications that will be describe at the item Results.

$\mathrm{EE}_{i}=Q_{\mathrm{o}}-Q_{\mathrm{b}}$

This saving must be converted in machine power $(W)$ through the COP from Eq. 1 and then converted into steam turbine flow $\left(F_{\mathrm{s}}\right)$ by division of machine power $(W)$ with turbine efficiency $(\eta)$ and steam enthalpy $\left(H_{\mathrm{S}}\right)$ according to Eq. 4:

$F_{\mathrm{s}}=W /\left(\eta \times H_{\mathrm{s}}\right)$.

The financial saving $\left(S_{\mathrm{C} 3}\right)$ is obtained by multiplying the vapor flow by its price $\left(P_{\mathrm{S}}\right)$, as shown in Eq. 5:

$S_{\mathrm{C} 3}=F_{\mathrm{s}} \times P_{\mathrm{s}}$.

To identify the modifications needed was performed a energy assessment with this steps:

- mass and energy balance calculation;

- design data conditions comparison;

- analysis of differences between the actual values and the design reference.

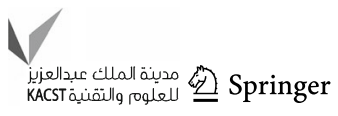




\section{Results}

The opportunities identified by this work are based on change the process conditions at the heat integration exchangers, as described below.

- EA-001: The optimum outlet temperature for C3R is $30{ }^{\circ} \mathrm{C}$. In the reference period used, from $01 / 01 / 2014$ to $31 / 06 / 14$, this average temperature was $15^{\circ} \mathrm{C}$. That shows a good opportunity to energy gain.

- EA-002A/B: The optimum outlet temperature for hot ethylene is $15^{\circ} \mathrm{C}$. This value is set for preventing vaporization and consequent internal damage to the exchanger tubes. It's close to the saturation temperature of ethylene in pressure conditions. In the same refer period, average temperatures were:

- EA-002A: $-3.94{ }^{\circ} \mathrm{C}$.

- EA-O02B: $17.26^{\circ} \mathrm{C}$.

Another good energy gain opportunity, especially on EA-002A.

- EA-003: Fig. 6 describe this system. To define the distribution of the bottom flow from demethanizer to deethanizer there is a manual input (HK-001) that controls the flow of FIC-001 and FIC-002, responsible for this distribution. There are too options, directly enter and pass by EA-003. The set value rate is $0-100 \%$.

The HK-001 commonly value used is $50 \%$ for operating agreement and a good practice adopted from a long time. At this condition, the thermal load exchanged in EA-003 was below the design reference, an energy gain opportunity.

The modifications for each exchanger are listed below.

EA-001: For this heat exchanger was necessary a Toluene washing on the maintenance turnaround that

\section{Demethanizer}

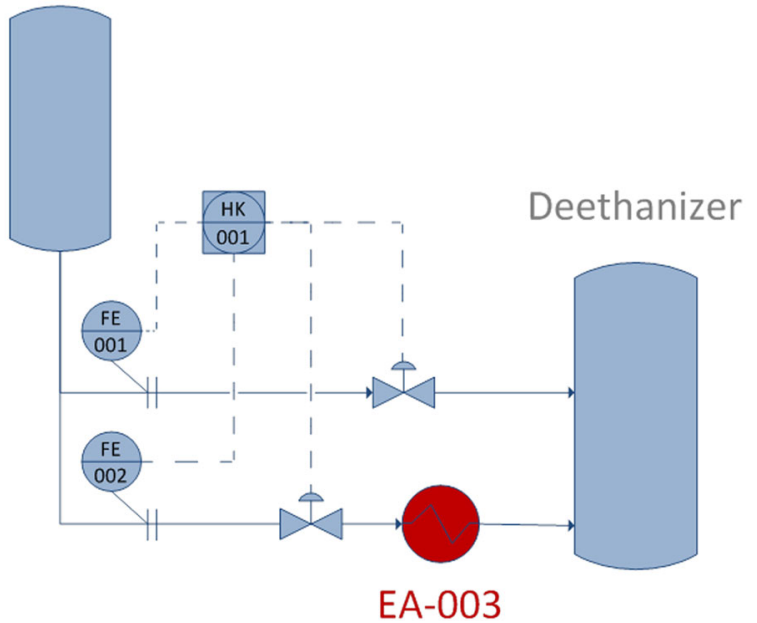

Fig. 6 Bottom demethanizer flow control occurred in September 2014. On this occasion the cleaning of the hot side (C3R) was performed to remove accumulated obstructions by oils and greases sending during the commissioning of new condensers that started operations. After this cleaning, it was possible to reach temperatures between 20 and $30^{\circ} \mathrm{C}$ depending on stability process.

$E A-002 A / B$ : For these two exchangers, the action was only set the Ethylene outlet temperature at $15^{\circ} \mathrm{C}$. No cleaning intervention was required for this action, only operational training.

EA-003: For this exchanger are defined two-step actions. The modifications was made only at the C3R side, the average conditions at the column, like specifications and process conditions, was maintained the same.

Manual optimization: is being held manual and gradual change of Deethanizer load parameter distribution (HK001) without causing disturbances in the tower and did not increase your reflux ratio for top specification.

Optimization through advanced control: is being developed advanced control that use HK-001 in optimization logic as a manipulated variable, setting a great value in an automatic way.

Appling these actions were possible to achieve the savings described at the Table 1. At the first column are listed the equipment optimized. At the second column is presented the energy efficiency saving by the modifications and calculated by Eq. 3. At the third are listed the consequent turbine work saving, calculated by Eq. 1 and considering the COP as 1.6. The fourth column list the equivalent steam calculated by the Eq. 4 and considering the turbine efficiency $19 \%$ and the steam enthalpy $3169.5 \mathrm{~kJ} / \mathrm{kg}$. The last column presents the financial saving, calculated by Eq. 5 and considering the steam price $0.030 \mathrm{US} \$ / \mathrm{kg}$.

\section{Conclusion}

It is proved that the still warm $\mathrm{C} 3 \mathrm{R}$ heat exchangers are important to the propylene refrigerant cycle energy efficiency, saving up more than one million dollar at 2015.

Table 1 Savings

\begin{tabular}{llllr}
\hline Equipment & $\begin{array}{l}\text { Energy efficiency } \\
\left(\mathrm{EE}_{i}\right)[\mathrm{MW}]\end{array}$ & $\begin{array}{l}\text { Turbine } \\
\text { work }[\mathrm{MW}]\end{array}$ & $\begin{array}{l}\text { Steam } \\
{[\mathrm{kg} / \mathrm{s}]}\end{array}$ & $\begin{array}{l}\text { Saving } \\
{[\mathrm{US} \$ / \mathrm{year}]}\end{array}$ \\
\hline EA-001 & 0.70 & 1.11 & 0.35 & $332,805.02$ \\
EA-002A/B & 0.69 & 1.11 & 0.35 & $331,760.34$ \\
EA-003 & 0.73 & 1.17 & 0.37 & $348,785.64$ \\
Total & 2.12 & 3.39 & 1.07 & $1,013,351.00$ \\
\hline
\end{tabular}


In terms of natural resources, this work is bringing an average reduction of $1.07 \mathrm{~kg} / \mathrm{s}$ of steam, representing an amount of approximately $2.12 \mathrm{MW}$. This gain is about $2 \%$ of the turbine consumption that represents $1 \%$ of the total steam generation in the same level of pressure.

The changes and enhancements were detailed and can be reproduced on any Ethylene plant that has similar equipment.

Open Access This article is distributed under the terms of the Creative Commons Attribution 4.0 International License (http:// creativecommons.org/licenses/by/4.0/), which permits unrestricted use, distribution, and reproduction in any medium, provided you give appropriate credit to the original author(s) and the source, provide a link to the Creative Commons license, and indicate if changes were made.

\section{References}

1. Pavan M (2008) Tradable energy efficiency certificates: the Italian experience. Energy Effic 1(4):257-266. doi:10.1007/ s12053-008-9022-x

2. Hopper N, Barbose G, Goldman C, Schlegelet J (2009) Energy efficiency as a preferred resource: evidence from utility resource plans in the Western US and Canada. Energy Effic 2(1):1-16. doi:10.1007/s12053-008-9030-x

3. Nässén J, Holmberg J (2009) Quantifying the rebound effects of energy efficiency improvements and energy conserving behaviour in Sweden. Energy Effic 2(3):221-231. doi:10.1007/ s12053-009-9046-x

4. Unachukwu GO (2011) Potential economic and social benefits of promoting energy efficiency measures in Nigeria. Energy Effic 4(4):465-472. doi:10.1007/s12053-011-9126-6
5. Bhole B, Surana S (2011) Electricity prices and state commitment to energy efficiency in the US. Energy Effic 4(1):9-16. doi:10. 1007/s12053-010-9085-3

6. Martínez CIP (2011) Energy efficiency development in German and Colombian non-energy-intensive sectors: a non-parametric analysis. Energy Effic 4(1):115-131. doi:10.1007/s12053-010-9078-2

7. Jollands N (2012) Ready, aim, implement: designing, implementing and evaluating energy efficiency targets-summary of a panel discussion, 10 June, Paris, France. Energy Effic 5(1):65-66. doi:10.1007/s12053-010-9105-3

8. Suzuki S, Nijkamp P, Rietveld P (2015) A target-oriented data envelopment analysis for energy-environment efficiency improvement in Japan. Energy Effic 8(3):443-446. doi:10.1007/ s12053-014-9297-z

9. Wu AH, Cao YY, Liu B (2014) Energy efficiency evaluation for regions in China: an application of DEA and Malmquist indices. Energy Effic 7(3):429-439. doi:10.1007/s12053-013-9232-8

10. Sathitbun-Anan S, Fungtammasan B, Barz M, Sajjakulnukit B, Pathumsawad S (2015) An analysis of the cost-effectiveness of energy efficiency measures and factors affecting their implementation: a case study of Thai sugar industry. Energy Effic 8(1):141-153. doi:10.1007/s12053-014-9281-7

11. Broeren MLM, Saygin D, Patel MK (2014) Forecasting global developments in the basic chemical industry for environmental policy analysis. Energy Policy 64:273-287. doi:10.1016/j.enpol. 2013.09.025

12. CNI—Confederação Nacional Da Indústria (2014) Indicador de custos industriais. Brasília

13. Santana DM, Lourenco SR, Cassiano DA (2015) A energia como um reverso saliente no sistema sociotécnico do Brasil. Interfaces Científicas Humanas e Sociais 3:113-122. doi:10.17564/23163801.2015v3n3p113-122

14. Bosco F (2014) Eficiência Energética: caminho para reduzir custos e emissões. Petro Química 359:22-23

15. U.S. Department of Energy (2012) Manufacturing energy and carbon footprint sector: chemicals. U.S. Department of Energy, Washington, DC 